\title{
Production and Economics of Turmeric Cultivation
}

\author{
K. Dhanalakshmi", K. Chitra, R. Manimekalai, \\ C. Balisasikumar and K. Karthikeyani Vijayakumari
}

Krishi Vigyan Kendra, Vamban, Pudkkottai, Tamil Nadu, India

\section{A B S T R A C T}

\begin{tabular}{|l|}
\hline Ke y w o r d s \\
$\begin{array}{l}\text { Turmeric (Curcuma } \\
\text { longa L.), Medicinal } \\
\text { purposes }\end{array}$ \\
\hline Article Info \\
\hline $\begin{array}{l}\text { Accepted: } \\
\text { 26 October } 2018 \\
\text { Available Online: } \\
\text { 10 November } 2018\end{array}$ \\
\hline
\end{tabular}

Keywords

Turmeric (Curcuma longa $\mathrm{L}$.), Medicinal purposes 10 November 2018

\begin{abstract}
Turmeric strictly speaking is a condiment crop which has been used for colouring, flavoring and medicinal purposes. Turmeric occupies prominent position among the spices produced in India. It ranks fourth in area and second in production. In the area of export, turmeric occupies second position in terms of quantity and fourth position in the export earnings among the spices. Turmeric the golden spice is widely cultivated in different countries such as India, China, Myanmar, Nigeria, Bangladesh, Pakistan, Sri Lanka, Taiwan, Indonesia etc. Among these countries, India occupies first position in area, and also in production. In India, turmeric is grown in 18 states and Andhra Pradesh, Tamil Nadu, Karnataka and West Bengal are the major turmeric producing states
\end{abstract}

\section{Introduction}

Indian turmeric cultivation and production trend has increased gradually over the past decades and also area of cultivation shows an increasing trend. India accounts for about 80 per cent of world turmeric production (Deepa KM). Turmeric (Curcuma longa L.), the ancient and sacred spice of India known as 'Indian saffron', is an important commercial spice crop grown in India.

It is known as the "golden spice" as well as the "spice of life" (Sahoo). India is a major supplier of turmeric to the world with more than 60 per cent share in turmeric trade (Angles S).Turmeric was probably cultivated at first as a dye, and then became valued as condiments as well as for cosmetic purposes. The Arab traders took turmeric to Europe in the thirteenth century during his travels in China in 1280 (Babu N.). Use of turmeric dates back nearly 4000 years to the Vedic culture in India. It is extensively used in Ayurveda, Unani and Siddha medicine as home remedy for various diseases (PreetiRathaur*). Exports in the year 2017-18 are expected to increase based on steady demand for the turmeric based product both in health and pharmaceutical sector (Karvy Comtrade Limited).

Tamil Nadu state occupies the second position in both production of and area under turmeric among all the states in India. Among the districts of Tamil Nadu state, Erode district stands first in both area and production of turmeric. In the year 2006-07, turmeric was cultivated in 7731 hectares in Erode district and the total production was 61813 tonnes $(\mathrm{N}$. 
Kiruthika). According to the Bureau of Indian Standards (BIS), 63 spices were grown in India. The spices were grown throughout the country from tropical to temperate climate. India has the highest number of spice varieties in the world (Sarfraz sheikh)

\section{Materials and Methods}

In Pudukottai district there are twelve blocks. Among the twelve blocks, Thirumayamis one of the block selected for study purpose. Data were collected from the primary sources namely Famer name, father name, address, age of the farmer, land holding, gender, community, educational qualification and contact number were collected from the selective farmer. For analyzing purpose gross cost, gross return, net return and benefit cost ratio were collected from the identified farmers. The per cent increased over the control was also calculated.

\section{Results and Discussion}

The average age of the sample Power Mix T adopters was found to be fifty years. Among the adopters 20 per cent of the farmers are illiterate and 50per cent of the farmers received secondary education and 30 per cent of them went for post matriculation. The analysis of the occupation pattern of the sample respondents revealed that all the sample farmers practiced agriculture as main occupation.

The average Turmeric growing area of the sample farmers found to be small and medium holding of land. The major soil type observed among the sample farmers is sandy clay loam and sandy loam. Studies showed that 40-55 per cent of soils are moderately deficient in micronutrients like $\mathrm{Zn}, \mathrm{Fe}, \mathrm{Cu}, \mathrm{Mn}$ and $\mathrm{Mg}$, while 25-30 per cent is deficient in B (Boron). Deficiency of other micronutrients occurs in 15 per cent of soils. These deficiencies/limitations reduce yield significantly (Fig. 1-4 and Table 1-5).

\section{Micro nutrient utilization pattern in turmeric}

For turmeric Power Mix T was recommended as a foliar spray at $5 \mathrm{gm}$ per litre of water once during sixty days after planting and another ninety days after planting are recommended. Micronutrients are those essential elements which are required by plants in very small amounts. Besides promoting plant metabolic activities and growth of the plants, they play a major role in improving quality, size, colour, taste, input use efficiency of fertilizers, water use, disease resistance

The resource farmers are using primary nutrients only for cultivating the turmeric. This might be due to lack of technical knowledge on micro nutrients / Power Mix T. which ultimately reduces the finger yield. They are lack of knowledge about use of proper organic inputs, recommended dose of fertilizers and soil based nutrient recommendations and plant protection chemicals which can boost their yield.

It was revealed that from the study that majority of the farmers were not adopting recommended dose of Micro Nutrients. The demonstrations need to be conducted to educate the farmers to adopt recommended application of Micro Nutrients.

The cost and return structure in Turmeric cultivation for one hectare is presented in the Tale 2. The total cost, the expenditure incurred on cultivation of turmeric was Rs. 43,000/ for control it was Rs. 40,000/. This indicates that the farmers are not adopting recommended practices on various inputs level. The Benefit Cost Ratio (BCR) was three point two (3.2), for control it was two point five (2.5). This was realized by the sample farmer. 
Table.1 Labour and cost utilization pattern in Turmeric production for One hectare

\begin{tabular}{|c|c|c|c|c|}
\hline $\begin{array}{l}\text { S. } \\
\text { No. }\end{array}$ & Description & $\begin{array}{l}\text { No. of } \\
\text { workers }\end{array}$ & $\begin{array}{ll}\text { Unit } & \text { Cost } \\
\text { (Rs) } & \end{array}$ & $\begin{array}{l}\text { Total cost } \\
\text { (Rs) }\end{array}$ \\
\hline 1 & Land preparation & 5 & 250 & 3000 \\
\hline 2 & Ploughing & 10 & 250 & 4000 \\
\hline 3 & Sowing & $10 \times 2$ & 250 & 5000 \\
\hline 4 & Mulch collection & 12 & 250 & 3000 \\
\hline 5 & Weeding & $5 \times 2$ & 250 & 10000 \\
\hline 6 & Harvesting & 15 & 250 & 7000 \\
\hline$\overline{6}$ & $\begin{array}{l}\text { Fertilizers and Micro Nutrient Mixtures } \\
\text {-Powermix T }\end{array}$ & & & 4500 \\
\hline 7 & Cleaning and grading & $3 \times 2$ & 250 & 2500 \\
\hline 8 & Boiling & $5 \times 2$ & 250 & 2500 \\
\hline 9 & Drying & $2 \times 3$ & 250 & 1500 \\
\hline & & & Total & 43000 \\
\hline
\end{tabular}

Table.2 Cost Return structure in Turmeric cultivation

\begin{tabular}{|c|c|c|c|c|c|c|c|c|c|c|}
\hline \multicolumn{6}{|c|}{ Treated } & \multicolumn{5}{|c|}{ Control } \\
\hline Field & $\begin{array}{l}\text { Y/ha } \\
\text { /q } \\
\text { (dry) }\end{array}$ & $\begin{array}{l}\text { Gross } \\
\text { cost } \\
(\text { Rs } / Q)\end{array}$ & $\begin{array}{l}\text { Gross } \\
\text { return } \\
\text { (Rs/Q) }\end{array}$ & $\begin{array}{l}\text { Net } \\
\text { return } \\
\text { (Rs/Q) }\end{array}$ & BCR & $\begin{array}{l}\text { Y/ha/q } \\
\text { (dry) }\end{array}$ & $\begin{array}{l}\text { Gross } \\
\operatorname{cost}(R \\
\text { s/Q) }\end{array}$ & $\begin{array}{l}\text { Gross } \\
\text { return } \\
\text { (Rs/Q) }\end{array}$ & $\begin{array}{l}\text { Net } \\
\text { return } \\
\text { (Rs/Q) }\end{array}$ & BCR \\
\hline F1 & 54 & 42000 & 135000 & 93000 & 3.2 & 46 & 42000 & 101200 & 59200 & 2.4 \\
\hline F2 & 53 & 45000 & 132500 & 87500 & 2.9 & 45 & 43000 & 99000 & 56000 & 2.3 \\
\hline F3 & 50 & 42000 & 125000 & 83000 & 3.0 & 43 & 46000 & 94600 & 48600 & 2.1 \\
\hline F4 & 54 & 44000 & 135000 & 91000 & 3.1 & 46 & 39000 & 101200 & 62200 & 2.6 \\
\hline F5 & 53 & 43000 & 132500 & 89500 & 3.1 & 46 & 37000 & 101200 & 64200 & 2.7 \\
\hline F6 & 55 & 42000 & 137500 & 95500 & 3.3 & 45 & 36000 & 99000 & 63000 & 2.8 \\
\hline F7 & 54 & 44000 & 135000 & 91000 & 3.1 & 47 & 42000 & 103400 & 61400 & 2.5 \\
\hline F8 & 56 & 43000 & 140000 & 97000 & 3.3 & 46 & 41000 & 101200 & 60200 & 2.5 \\
\hline F9 & 57 & 43000 & 142500 & 99500 & 3.3 & 47 & 43000 & 103400 & 60400 & 2.4 \\
\hline F10 & 56 & 42000 & 140000 & 98000 & 3.3 & 47 & 38000 & 103400 & 65400 & 2.7 \\
\hline $\begin{array}{l}\text { Aver } \\
\text { age }\end{array}$ & 54.2 & 43000 & 135500 & 92500 & 3.2 & 45.8 & 40700 & 100760 & 60060 & 2.5 \\
\hline
\end{tabular}


Table.3 Yield returns in turmeric cultivation

\begin{tabular}{|c|c|c|}
\hline \multirow{2}{*}{ Field } & $\begin{array}{c}\text { Treated } \\
\text { Y/ha/q (dry) }\end{array}$ & $\begin{array}{c}\text { Control } \\
\text { Y/ha/q (dry) }\end{array}$ \\
\hline F1 & 54 & 46 \\
\hline F2 & 53 & 45 \\
\hline F3 & 50 & 43 \\
\hline F4 & 54 & 46 \\
\hline F5 & 53 & 46 \\
\hline F6 & 55 & 45 \\
\hline F7 & 54 & 47 \\
\hline F8 & 56 & 46 \\
\hline F9 & 57 & 47 \\
\hline F10 & 56 & 47 \\
\hline
\end{tabular}

Table.4 Cost return structure in turmeric cultivation

\begin{tabular}{|l|c|c|}
\hline & Treated & Control \\
\hline Field & Net return $(\mathbf{R s} / \mathbf{Q})$ & Net return $(\mathbf{R s} / \mathbf{Q})$ \\
\hline F1 & 93000 & 59200 \\
\hline F2 & 87500 & 56000 \\
\hline F3 & 83000 & 48600 \\
\hline F4 & 91000 & 62200 \\
\hline F5 & 89500 & 64200 \\
\hline F6 & 95500 & 63000 \\
\hline F7 & 91000 & 61400 \\
\hline F8 & 97000 & 60200 \\
\hline F9 & 99500 & 60400 \\
\hline F10 & 98000 & 65400 \\
\hline
\end{tabular}

Table.5 Constrains faced by the turmeric cultivation in study area

\begin{tabular}{|l|l|l|}
\hline S. No. & Constrains & Per cent \\
\hline 1. & Personal obligation with traders & 20.7 \\
\hline 2. & Financial weakness & 68.4 \\
\hline 3. & Lack of technical knowledge & 78.6 \\
\hline 4. & Lack of storage facility & 46.2 \\
\hline 5. & Low productivity & 46.8 \\
\hline 6. & Non availability of quality planting material & 82.3 \\
\hline 7. & Adequate market information & 33.5 \\
\hline
\end{tabular}


Fig.1 Cost return structure in turmeric cultivation

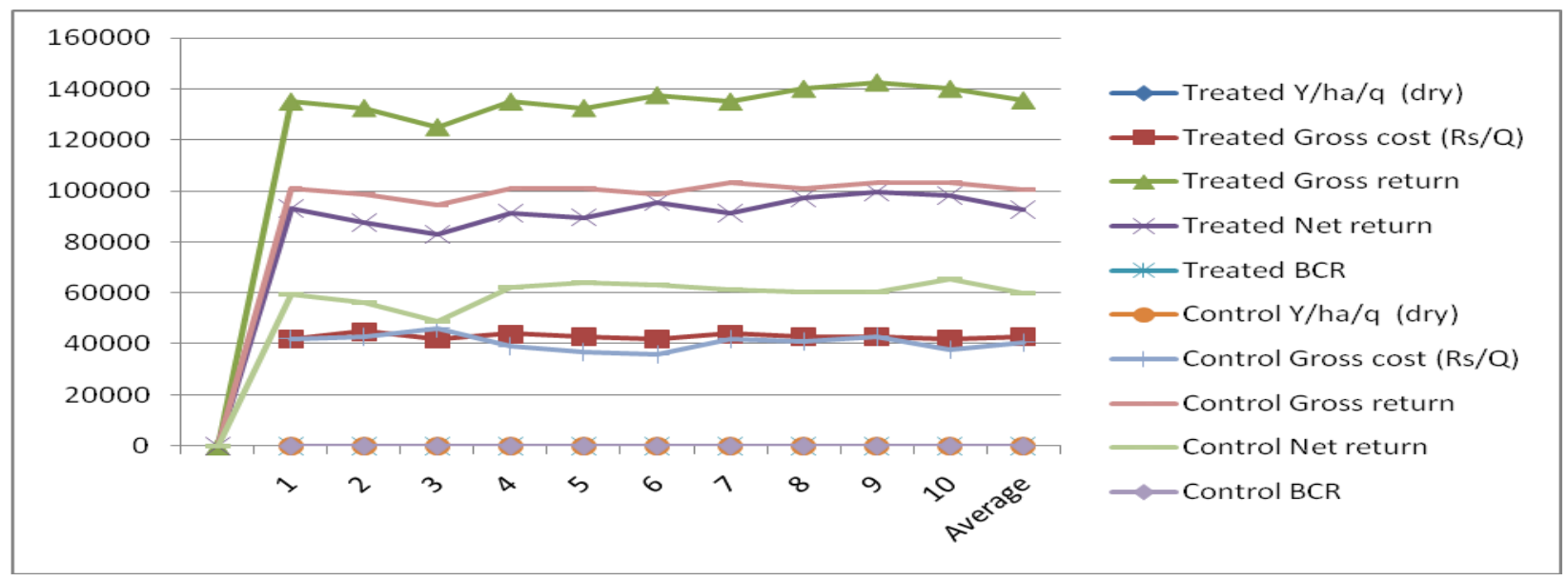

Fig.2 Yield returns in turmeric cultivation

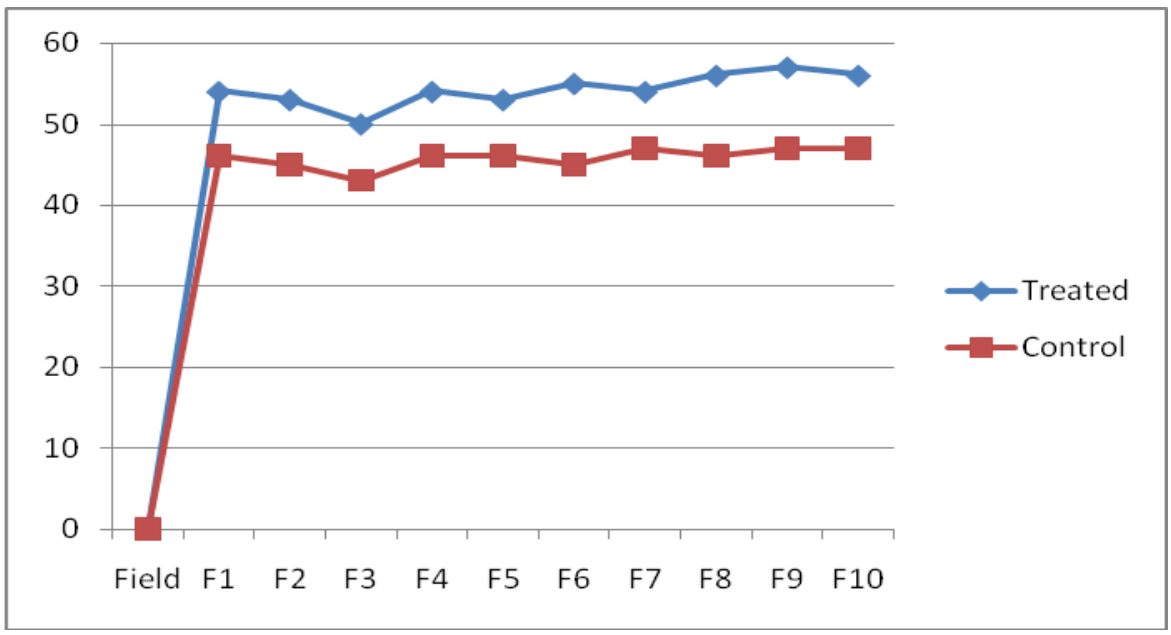

Fig.3 Cost Return structure in turmeric cultivation

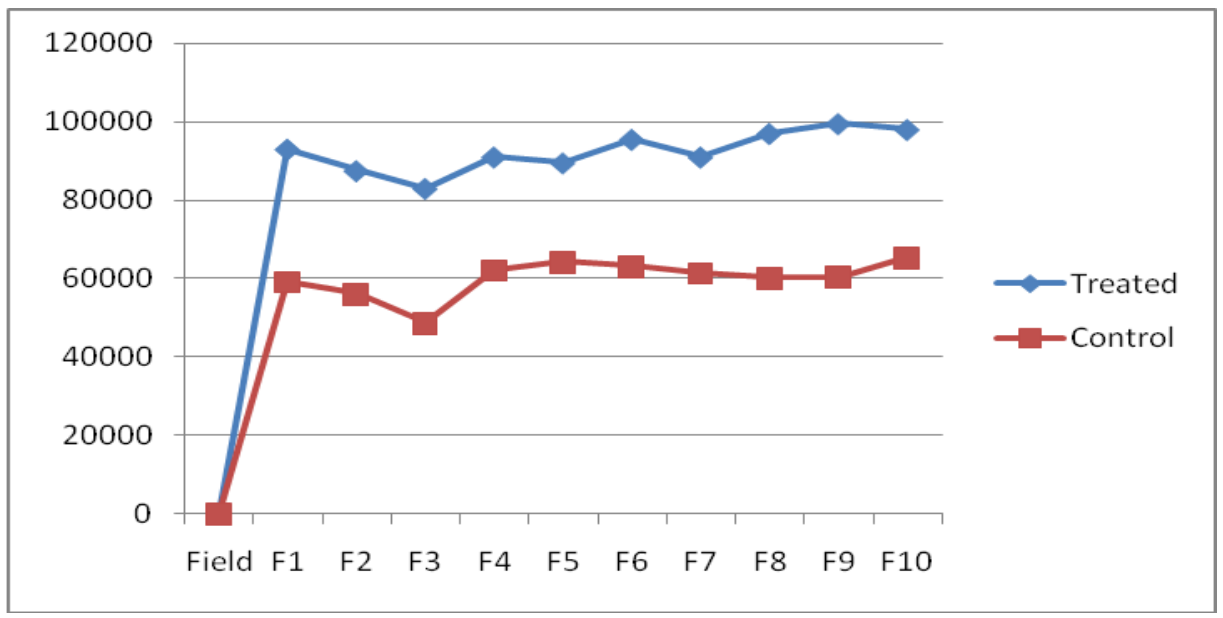


Fig.4 Constrains faced by the turmeric cultivation in study area4

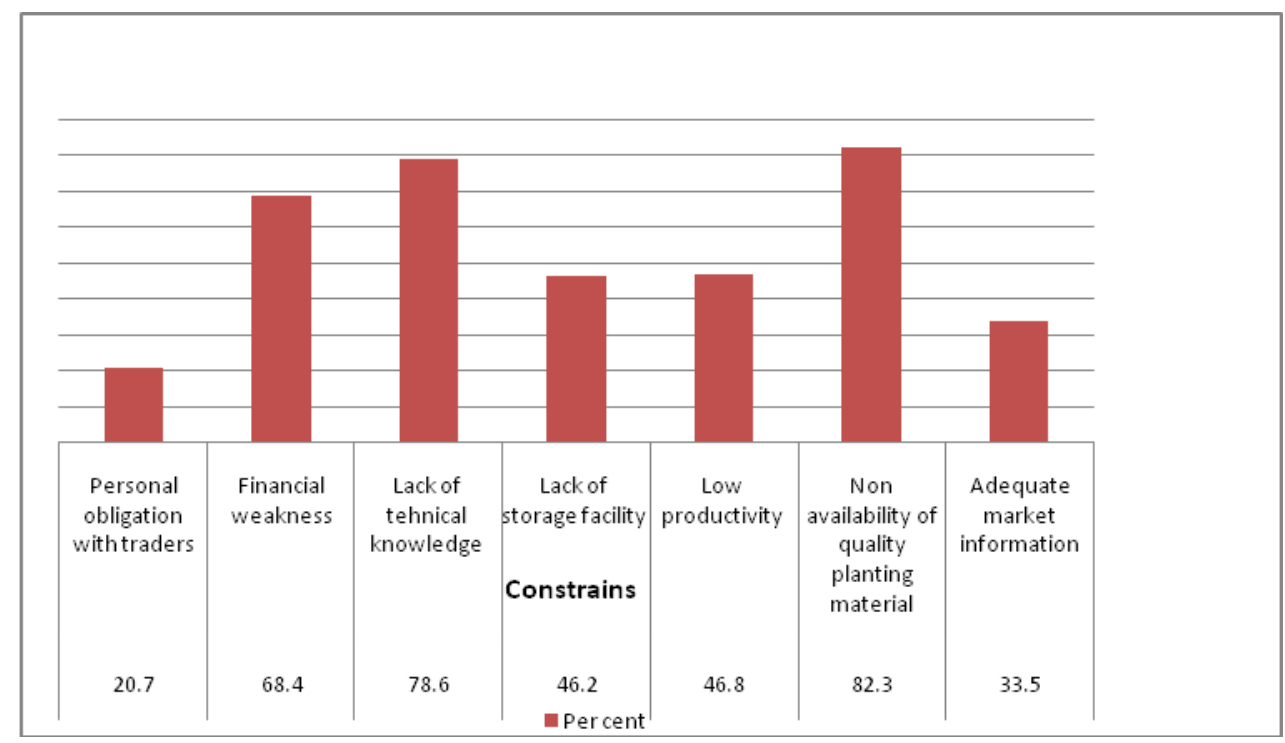

The total cost of dried Turmeric production of the sample farmer was 54.2, concern with untreated it was $45.8 \mathrm{q} / \mathrm{ha}$. Similar results were obtained by the Deepa (2010), Umagowri (2011) in their study on cost of commercial production and seed production of cotton.

\section{Constrains faced by the turmeric cultivation in study area}

The major constrains faced face by the turmeric growers in cultivation of Turmeric in this study area presented in Table 3. The selective farmers faced and realized and the study revealed that the major problem faced by the growers in production are nonavailability of good seed material in appropriate time, lack of technical knowledge, lack of knowledge on importance of micro nutrient, inadequate market information and low productivity.

Turmeric is one of the most important spice crop in or country. However the productivity is continuously decreasing year by year. There is need to increase the proclivity to fulfill the domestic requirement and for export turmeric cultivation is capital intensive and needs more investment. It has been observed that technological interventions like rhizome treatment, soil application of biocontrol agents, manures, fertilizers, Micro Nutrients, crop rotation, mulching and correct form of plant protection measures, increasing the yield performance by $20-25$ per cent. To enhance the productivity, ecofriendly production technology among the farming community are the need of the hour.

\section{References}

Angles S, Sundar A, Chinnadurai M. Impact of globalization on production and export of turmeric in India - An economic analysis. Agricultural Economics Research

Babu N, Shukla AK, Tripathy PC, Prusty M. Traditional cultivation practices of turmeric in tribal belt of Odisha. Journal of Engineering Computers \& Applied Sciences. 2015; 4(2):52-57.

Deepa KM. Turmeric: The golden spice, Facts for You. Sept. 19-20; 2010.

Karvy Comtrade Limited. Annual commodity report, tTrmeric, Karvy Ltd.; 2017. 
Kiruthika, N. The economics of production of turmeric in India: a case study of erode district of Tamil Nadu, Journal of Innovative Research and Solutions (JIRAS) Print, 2013, 1(1):23- 30

PreetiRathaur, Waseem Raja, P.W. Ramteke and Suchit A. John, Turmeric: The golden spice of life, Department of Biological Sciences, Sam Higginbottom Institute of Agriculture 2012, 3(7): 1987-1994

Sahoo PP. Value Chain Analysis of Organic Turmeric In Kandhamal District of
Odisha. M.Sc (Agri) Thesis, Orissa University of Agriculture and Technology (India); 2017.

Sarfraz sheikh, Raghavendrachourad, Shreyaamarapurkar and Raghavendrakondaguri. Economics of turmeric production under conventional and modern methods in Belgaum district of northern Karnataka, International Journal of Commerce and Business Management, 2014, 7(1):100104

\section{How to cite this article:}

Dhanalakshmi, K., K. Chitra, R. Manimekalai, C. Balisasikumar and Karthikeyani Vijayakumari, K. 2018. Production and Economics of Turmeric Cultivation. Int.J.Curr.Microbiol.App.Sci. 7(11): 3496-3502. doi: https://doi.org/10.20546/ijcmas.2018.711.399 